\title{
Relation of Albanian Standard Language to Dialects, Sociolects, Idiolects: The Linguistic Situation at the University of Vlora
}

\author{
Dr. Dorjana Klosi \\ English language department, Faculty of human sciences \\ University of "Ismail Qemali"; dorianaklosi@gmail.com \\ Doc. Lulzim Hajnaj \\ Department of education, Faculty of human sciences \\ University of "Ismail Qemali"; Iulzimhajnaj@yahoo.com \\ Dr. Evis Celo \\ English language department, Faculty of human sciences \\ University of "Ismail Qemali"; evis.celo8@gmail.com
}

Doi:10.5901/ajis.2015.v4n3s1p359

\section{Abstract}

\begin{abstract}
Albanian language and its components have always been in constant change. Economic and political issues, religious changes and life styles have affected language as well. Albanian standard language is trying to maintain a high profile for its users. However, it is facing an enormous linguistic change. Dialects, sociolects and idiolects are some of the main sources that affect and enrich language. How language and its components interact with each other? How are dialects, Geg and Tosk, represented on standard Albanian language? How is the actual linguistic performance in relation to linguistic contexts? At what extend are idiolects and sociolects represented at standard language? These and more questions are the center of our research paper.
\end{abstract}

Keywords: linguistics, standard language, dialects, idiolects.

\section{Objectives}

* Identifying linguistic situations at the University of Vlora;

* Exploring the spread and usage of urban dialectology at University campus;

\& Determining the factors that influence the spread of urban dialectology;

* Verifying the extend of usage of standard language in and outside the auditoriums;

* Explaining the linguistic exchange among literary forms, dialectical and idiolectical features.

\section{Theoretical Framework}

Now days, sociolinguistic studies, in Albania and abroad, are mainly focused on urban dialectology and its influence on the standard language. Urban dialectology has affected many usages of languages, in various linguistic contexts. University campuses are good examples where to study such linguistic varieties. All the specter of linguistic varieties is the object of study of our research paper. Nevertheless, foreign and home literature has given to our study another dimension and importance. 


\section{Results}

Communication in the same language has great advantages ${ }^{1}$ :

- Avoidance of misunderstanding;

- Better communication;

- Unifies the system of education. Standard language provides its users with a great sense of unity and it is a national patrimony.

Standard language, as a special variant of the national language, has a higher status than the other linguistic variants. It has always had a leading role in the process of development of language and its usage. Albanian language determines the communication at institutions, such as universities, schools, ministries and other governmental institutions, the media, etc².

In Albania, the attendance of primary and secondary schools is compulsory. However, it is premeditated to state that compulsory school attendance is enough to gain the

The Standard follows certain rules and guidelines in both areas: speech and writing ${ }^{3}$. But there are a number of paralinguistic factors that affect speech and writing, more specifically grammar, vocabulary and pronunciation. Due to this, paralinguistic factors are essential aspects for the development and functionality of language itself ${ }^{4}$.

Albanian linguist Prof. A. Dodi claims that "Linguistics has mostly focused on explaining language through linguistic features. But the negation or underestimation of paralinguistic features is wrong and does not contribute in explaining lots of linguistic phenomenon". Thus, certain variables (culture, education, etc.,) affect standard language 5 .

Phonetic structure of the standard form constantly borrows linguistic elements from both Albanian dialects. For instance: standard language is based on the Southern dialect, the Tosk, but it is widely accepting forms from the Northern dialect, the $\mathrm{Geg}^{6}$. The standard language has welcomed both forms of ë (Southern) and a (Northern): za-zë; baj-bëj; nana-nënë, and so on. As a result, the usage of forms from both dialects has brought into light new phonetic elements.

A look at the linguistic situation at school is a proof of the aforementioned claim. It opens a question about the spread and usage of the standard language at certain institutions related to education, such as schools and universities.

Various observations, questionnaires and discussions made with students of University of Vlora have put into light several linguistic deviations, in and out the auditoriums.

University of Vlora welcomes students from all over Albania. Thus, linguistic discourses on campus are full of personal and dialectical linguistic features. Numerous linguistic deviances from the standard language are somewhat reflected inside the class. But, such deviances are quite obvious outside the auditoriums. No matter the topic of conversation or kinds of contexts the students find themselves in, they cannot escape their family or regional background.

\section{Case Study}

In order to measure linguistic diversity at university we used a questionnaire. The purpose was to identify the degree of acknowledgement that students have of standard language. 100 students of different branches and grades took part in the study. They were introduces to several questions about the usage of standard forms in and outside the class.

\footnotetext{
${ }^{1}$ Lloshi, Xh., Stilistika e Gjuhës Shqipe, Tiranë, 2001. f.150.

${ }^{2}$ D, Chrystal-D., Davy, Investigating English Style, London, 1969, f. 64.

${ }^{3}$ Paçarizi, Rr., Rruga e zhvillimit të shqipes standard në raport me nevojat e komunikimit, Tiranë, 2011, f. 6.

${ }^{4}$ Keranen, N., \& Bayyurt, Y., Bridging the Gap Between Teaching Styles and Learning Styles: A Cross-Cultural Perspective, United States. 2006, f. 1.

${ }^{5}$ Dodi, A, Fonetika dhe fonologjia e gjuhës shqipe, Tiranë, 2004, f. 128

${ }^{6}$ Gjinari, J., \& Shkurtaj, Gj., Dialektologjia, Tiranë, 2003, Kotrri, P., \& Topalli, T., Gjuha dhe ligjërimi në shkollë në kuadrin e shqipes standard, Tiranë 2003, f. 407.
} 
How much do you know of standard linguistic forms?
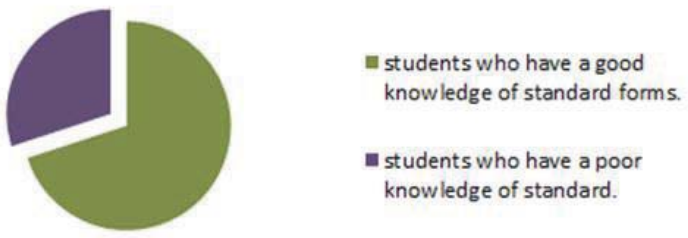

$70 \%$ of students admitted to have a good knowledge of standard forms and when they should use such forms. $30 \%$ of them did not show a good knowledge of standard language.

What register do you use with your friends, standard forms of colloquial language?

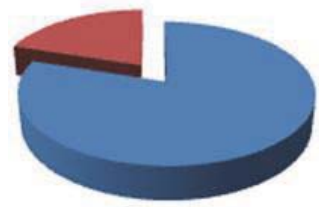

IIsers of colloquial speech and slang

n Përdorues të standardid.

$80 \%$ of students use colloquial forms and slang in such conversations and $20 \%$ of them use standard forms.

\section{Standard language is based on Geg or Tosk dialect?}

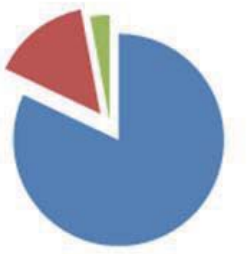

Elbanian standard language is based on Tosk.

E Albanian standard language is based on both dialects.

in Gjuha standarde baz ohet në gegërishte.

$82 \%$ of students choose "Tosk"; $15 \%$ choose "both dialects" and $3 \%$ choose "Geg".

Standard language is used in "

$$
\text { Public places Schools Media Institutional documents }
$$

All above alternatives

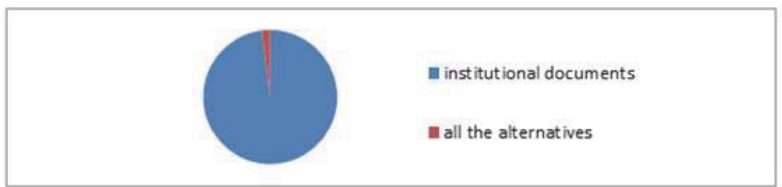

Choose the Correct Version

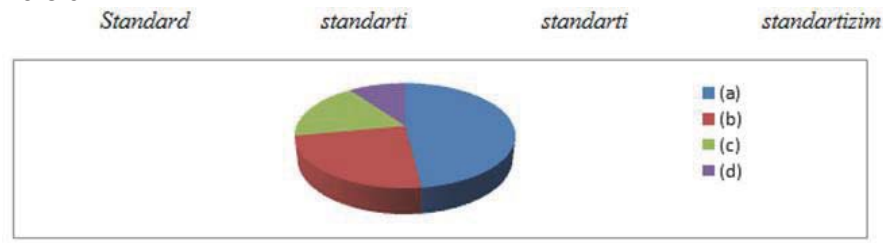


$48 \%$ choose variant Standard; $24 \%$ choose Standarti; $18 \%$ choose Standarti and $10 \%$ choose Sstandartizim.

\section{Which Linguistic Variant (Formal / Informal) do you use with your Professors?}

$90 \%$ of students use standard forms and $10 \%$ use a simple language, with simple linguistic forms. Below are some examples in Albanian language:

Student 1. Mund të m'a shpjegoni dhe njëherë ju lutem, se nuk e kam shumë të qartë.

Student 2. Presore të lutem, mund të më bëni një përmbledhje për këtë çështje se nuk e kuptova?

Student 3. Ju lutem mund të m'a shpjegosh edhe një herë pjesën e fundit të mësimit sepse nuk e kam kuptuar dhe kam nevojë për një sqarim të dytë?

Student 4. Ka mundësi t'a shpjegoni edhe një herë?

Student 5. Presore, të lutem mund t'a shpjegosh përsëri? Nuk e kam shumë të qartë.

Student 6. Presore, të lutem mund t'a shpjegosh përsëri këtë pjesë, po nuk e patët bezdi?

Student 7. Këtë pjesë e kisha shumë të vështirë për t'a kuptuar, mund t’a shpjegoni edhe një herë?

\section{Discussion}

The questionnaire and observations put into light some features of linguistic situation at the University of Vlora. Though students gave their answers for each question on the questionnaires, accurate observations came up with somewhat different results.

It was proved that $50 \%$ of students, instead of $70 \%$, have quite a good knowledge of the rules of speaking according to the standard language; $20 \%$ of them have a good knowledge of standard forms; $30 \%$ of students have a linguistic performance below average. Their speech is full of dialectical forms and linguistic deviances from the standard language.

$20 \%$ of students use standard forms in everyday speech. Close observation to the students' discourse showed that that "20\%" which pretend to avoid colloquial forms in such situations use plenty of everyday speech linguistic features. The subjective and emotional feelings of the interlocutors were quite obvious in their discourses.

In this case, the concept of Daniel Long "quasi standard' forms explains the results. In our case, speakers have the perception of using standard forms in their discourses. But, in fact, they are using nonstandard forms. Thus, codeswitching is the linguistic phenomena that characterize students' discourse.

As a result of geographic relativity, the University of Vlora linguistic situation is characterized by a combination of linguistic forms of standard language, dialects and idiolects. Students try as much as possible to use academic language in class and avoid colloquial elements. Their speech is marked by a great number of features belonging to everyday speech and slang in informal contexts.

\section{References}

D, Chrystal-D., Davy, Investigating English Style, London, 1969, f. 64.

Lloshi, Xh., Stilistika e Gjuhës Shqipe, Tiranë, 2001. f.150.

Dodi, A., Fonetika dhe fonologjia e gjuhës shqipe, Tiranë, 2004, f. 28

Paçarizi, Rr., Rruga e zhvillimit të shqipes standard në raport me nevojat e komunikimit, Tiranë, 2011, f. 6.

Gjinari, J., \& Shkurtaj, Gj., Dialektologjia, Tiranë, 2003, Kotrri, P., \& Topalli, T., Gjuha dhe ligjërimi në shkollë në kuadrin e shqipes standard, Tiranë 2003, f. 407.

Keranen, N., \& Bayyurt, Y., Bridging the Gap Between Teaching Styles and Learning Styles: A Cross-Cultural Perspective, United States. 2006, f. 1. 